\title{
Evaluation of HA negatively charged membranes in the recovery of human adenoviruses and hepatitis $A$ virus in different water matrices
}

\author{
C Rigotto' ${ }^{1+}$, CK Kolesnikovas', V Moresco', CMO Simões², CRM Barardi \\ 'Departamento de Microbiologia e Parasitologia ²Departamento de Ciências Farmacêuticas, Laboratório de Virologia Aplicada, \\ Universidade Federal de Santa Catarina, Florianópolis, SC, Brasil
}

\begin{abstract}
Human adenoviruses (HAdV) and hepatitis A virus (HAV) are shed in the faeces and consequently may be present in environmental waters, resulting in an increase in pathogen concentration that can affect water quality and human health. The aim of this study was to evaluate an adsorption-elution method which utilizes negatively charged membrane HA to determine the efficient recovery of HAdV and HAV from different water matrices and to combine this procedure with a qualitative molecular method (nested RT-PCR and nested PCR). The best efficiency recovery was achieved in distilled water and treated wastewater effluent (100\%) for both viruses and in recreational lagoon water for HAV (100\%). The efficiency recovery was $10 \%$ for HAdV and HAV in seawater and $10 \%$ for HAdV in lagoon water. The viral detection limit by nested PCR for HAV in water samples ranged between 20-0.2 FFU/mL and 250 and $25 \mathrm{TCID50/mL} \mathrm{for} \mathrm{HAdV.} \mathrm{In} \mathrm{conclusion,} \mathrm{these} \mathrm{results} \mathrm{suggest} \mathrm{that} \mathrm{the} \mathrm{HA} \mathrm{negatively} \mathrm{charged} \mathrm{membranes} \mathrm{vary} \mathrm{their}$ efficiency for recovery of viral concentration depending upon the types of both enteric viruses and water matrices.
\end{abstract}

Key words: virus recovery - negatively charged membrane - environmental waters - hepatitis A virus - adenovirus - PCR

Human enteric viruses are excreted in the faeces of infected patients in high concentrations and transmitted mainly by the faecal-oral route via contaminated food and water. Viruses are the major cause of water-related disease and have been estimated to cause about $30-90 \%$ of gastroenteritis cases worldwide (Bosh et al. 2008). Enteric viruses represent diverse and commonly studied groups of enteric viruses belonging to the families $P i$ cornaviridae [polioviruses, enteroviruses, coxsackieviruses, hepatitis A virus (HAV) and echoviruses], Adenoviridae (adenoviruses), Caliciviridae (noroviruses and saporovirus), Astroviridae (astroviruses) and Reoviridae (rotaviruses). Enteric virus groups are considered to be emerging waterborne pathogens based on their cellular and molecular structures that make them resistant to current water treatment processes (Fong \& Lipp 2005). Traditionally, bacterial indicators, such as faecal coliforms, have been used as indicators of water quality; however, it has been clearly established worldwide that bacterial standards do not always reveal the presence of viruses in environmental waters (Formiga-Cruz et al. 2002, Pusch et al. 2005). This fact is due mostly to the different physi$\mathrm{cal} /$ chemical properties of viruses and bacteria (Hsu et al. 2007). In recent years, many researchers have demonstrated the presence of human enteric viruses in several sources of water samples such as raw sewage (FormigaCruz et al. 2005), treated sewage (Harwood et al. 2005), river water (Borchardt et al. 2004) seawater (Katayama et

Financial support: CNPq, (473041/2007-3)

+ Corresponding author: crigotto@yahoo.com.br

Received 19 March 2009

Accepted 23 September 2009 al. 2002) and tap water (Lee et al. 2005), using molecular amplification techniques (PCR). PCR has become a major tool for detection and various types of viruses have been isolated in surface water by PCR, including fastidious viruses. PCR can also contribute to epidemiological studies because it is capable of differentiating specific viruses and also different genotypes of the same virus through the use of specific primers (Kinsgley \& Richard 2001). Because usually only a few viral particles are present in water samples, it is necessary to concentrate the viruses from a large volume of water. Different viral filtration methods, such as cartridge filters (electropositive or electronegative), associated with conventional viral isolation in cell cultures and/or molecular methods for virus detection have been developed to collect and concentrate viral particles from water samples (Fong $\&$ Lipp 2005). However, viral recoveries from various types of water are not always similar due to the fact that adsorption of viruses to the charged membranes may be influenced by salts, multivalent cations or acid conditions (Haramoto et al. 2005, 2006, 2007, Hsu et al. 2007, Victoria et al. 2009). Katayama et al. (2002) described an adsorption-elution method followed by ultrafiltration for virus detection in water samples using poliovirus as a model. This procedure included the addition of $\mathrm{MgCl}_{2}$ to water samples to adsorb viruses onto negatively charged membranes, an essential step that permits viral retention on the membrane. Victoria et al. (2009) evaluated this adsorption-elution method using different $\mathrm{MgCl}_{2}$ concentrations to achieve the best virus recovery of norovirus and astrovirus in water samples.

In our study we evaluated the efficiency of recovery of HAV and human adenoviruses (HAdV) by applying the adsorption-elution method using an HA negatively charged membrane with minor modifications (Katayama et al. 2002), followed by molecular amplification (nested 
RT-PCR and nested PCR) for virus detection in four different kinds of waters (seawater, lagoon water, treated wastewater effluent and distilled water).

\section{MATERIALS AND METHODS}

Cells and viruses - FRHk-4 cells (rhesus kidneyderived cells) and Hep-2 cells (a continuous line of human oropharyngeal carcinoma) were obtained from the American Type Culture Collection (ATCC ${ }^{\circledR}$, The Global Bioresource Center, USA). Cells were cultured in a $\mathrm{CO}_{2}$ atmosphere at $37^{\circ} \mathrm{C}$, in Eagle's minimal essential medium supplemented with $10 \%$ foetal bovine serum (GIBCO/BRL, Life Technologies do Brasil Ltda, São Paulo, SP, Brazil), streptomycin $(100 \mu \mathrm{g} / \mathrm{mL})$, penicillin $\mathrm{G}(100$ $\mathrm{U} / \mathrm{mL})$ and amphotericin $(0,025 \mu \mathrm{g} / \mathrm{mL})$ (Gibco-BRL). HAV (strain HM 175) was propagated in FRHk-4 cells as reported (Cromeans et al. 1987) and HAdV5 (genogroup C, serotype 5) in Hep-2 cells (Bardell 1983). For determination of virus titers, an indirect immunofluorescence assay was used for HAV, as previously described (Barardi et al. 1999), and the $\mathrm{TCID}_{50}$ assay was the method of choice for HAdV5 (Reed \& Muench 1938).

Water samples - Five hundred millilitres of each water sample (seawater, recreational lagoon water, treated wastewater effluent and distilled water) were collected from Florianópolis city in South Brazil. All water samples were autoclaved at $120^{\circ} \mathrm{C}$ for $30 \mathrm{~min}$ before the standardization of the method. These matrices were selected in order to ascertain the recovery of this method in different environmental waters to further apply for the testing of field samples. Distilled water was included as the "gold standard" for the method (inhibitor free) because different inhibitory compounds can be present in environmental samples.

Virus concentration method - In order to evaluate the efficiency of the method for viral recovery from different water matrices and to define the limit of sensitivity for virus detection using molecular methods, $500 \mathrm{~mL}$ of distilled water, lagoon water and treated wastewater effluent were spiked with $\mathrm{HAdV}\left(10^{7} \mathrm{TCID}_{50} / \mathrm{mL}\right)$ and $\mathrm{HAV}\left(3 \times 10^{4} \mathrm{FFU} / \mathrm{mL}\right)$ and the seawater was spiked with with HAdV $\left(10^{8} \mathrm{TCID}_{50} / \mathrm{mL}\right)$ and HAV $\left(3 \times 10^{5} \mathrm{FFU} / \mathrm{mL}\right)$. All water samples were spiked in triplicate, with inocula of the same viruses before and after (positive control) the method for concentration of virus. For each matrix of water, a negative control without spiking of virus was performed in order to verify the absence of any natural contaminants. Concentration of viruses in water was performed by adsorption onto an electronegative membrane and subsequent elution, as described by Katayama et al. (2002) with minor modifications. Briefly, an HA (mixed cellulose esters) negatively charged membrane (Nihon Millipore ${ }^{\circledR}$, Tokyo, Japan) with a pore size of $0.45 \mu \mathrm{m}$ and $142 \mathrm{~mm}$ diameter was placed into a vacuum pump and viruses were then adsorbed in the presence of $25 \mathrm{mM} \mathrm{MgCl}_{2}$ (the exception to this was seawater). The membrane was rinsed with $350 \mathrm{~mL}$ of $\mathrm{H}_{2} \mathrm{SO}_{4}(0.5 \mathrm{mM}$, $\mathrm{pH}$ 3.0) to elude the cations and subsequently treated for 10 min with $10 \mathrm{~mL}$ of $\mathrm{NaOH}(1.0 \mathrm{mM}, \mathrm{pH} 10.5)$ to allow the elution of viruses. The filtrate was neutralized with
$50 \mu \mathrm{L}$ of $50 \mathrm{mM} \mathrm{H}_{2} \mathrm{SO}_{4}$ and 100X TE buffer (pH 8.0) and then immediately ultrafiltered using a Centriprep Concentrator $50^{\circledR}$ system (Nihon Millipore ${ }^{\circledR}$, Tokyo, Japan) at $1500 \mathrm{~g}$ for $10 \mathrm{~min}$ at $4^{\circ} \mathrm{C}$ to obtain a final volume of 2 $\mathrm{mL}$. Four hundred microliters of this $2 \mathrm{~mL}$ was further used for nucleic acid extraction.

Nucleic acid extraction - Viral nucleic acids were extracted by a procedure described by Boom et al. (1990). This procedure is a simple and inexpensive alternative for nucleic acid extraction and it uses guanidinium thiocyanate for adsorption of the nucleic acids to silica particles. In order to reduce the presence of PCR inhibitors and verify the sensitivity of the nested PCR, RT-PCR or nested RT-PCR, prior to nucleic acid extraction, a 10 -fold serial dilution of each concentrated seeded water sample was performed in a sterile (autoclaved) water sample. For instance, the seeded Lagoon water was diluted in sterile Lagoon water and so forth. The viral detection limit was considered to be the highest virus dilution that demonstrated a positive result.

Nested reverse transcription-PCR and nested PCR to detect HAV and HAdV in water samples - Reverse transcription and genome amplification were performed using random and specific primers. Random hexamers primers were purchased from Promega (Brazil) and were used for cDNA synthesis. Briefly, a 5.0 $\mu \mathrm{L}$ aliquot of RNA was heated at $99^{\circ} \mathrm{C}$ for $5 \mathrm{~min}$, followed by quick chilling on ice for $2 \mathrm{~min}$. The denatured RNA was added to a mixture containing random primers, $50 \mathrm{mM}$ Tris$\mathrm{HCl}, \mathrm{pH} 8.4,75 \mathrm{mM} \mathrm{KCl}, 0.5 \mathrm{mM}$ of each dATP, dCTP, dTTP and dGTP, 20U of RNAse inhibitor and $100 \mathrm{U}$ of M-MLV reverse transcriptase (all reagents were purchased from Promega, Brazil), in a $25 \mu \mathrm{L}$ total volume. Reverse transcription of viral genomic RNA was carried out at $37^{\circ} \mathrm{C}$ for $60 \mathrm{~min}$.

HAV RNA was detected in sewage sludge and wastewater samples by nested RT-PCR, using the oligonucleotide primer pairs F6 (+) and F7 (-), which amplifies a 392 bp fragment, suitable to amplify all HAV genotypes ("universal primers"). Internal primers were F8 (+) and F9 (-), which amplifies a 247 bp fragment (de Paula et al. 2004).

AdV DNA was detected in samples using the oligonucleotide primer pairs hexAA 1885 /hexAA 1913 and nexAA 1893/nexAA 1905 described by Allard et al. (1992). The expected size of the PCR product was 300 bp and 142 bp for nested PCR.

Amplified fragments of HAdV and HAV were visualized by standard gel electrophoresis of $10 \mu \mathrm{L}$ of final reaction mixture in $1 \%$ agarose gels stained with ethidium bromide $(1 \mu \mathrm{g} / \mathrm{mL})$.

Quality control - To avoid the number of false positives resulting from carryover contamination of amplified virus particles or viral nucleic acid, separate areas and equipment were used for each stage of the process. Negative controls (non spiked autoclaved distilled water) and positive controls (virus suspensions) were included with each set of test samples and used throughout the nucleic acid extraction and the nested PCR and nested 
RT-PCR assays. Additional blank controls containing the same reaction mixture except for the nucleic acid template were incorporated alongside all PCR assays.

\section{RESULTS}

Tables I and II list the recoveries of HAdV and HAV, respectively, from different kinds of environmental waters. We obtained the same viral detection limit for the independently carried out triplicates for all samples.

The negative control, without virus spiking, was negative by nested RT-PCR for HAV and nested PCR for HAdV. Viral recoveries were calculated based on the following statement: water samples spiked with viruses after the concentration method were considered positive controls, indicating $100 \%$ virus recovery; water samples spiked before the concentration method with the same viral inocula were the tested samples from which the recovery was calculated. The best recovery was achieved in distilled water and treated wastewater effluent (100\%) for both viruses and in the lagoon water for HAV (100\%). The lowest efficient recovery (10\%) obtained was in seawater for both viruses and in lagoon water for HAdV. The viral detection limit by nested RT-PCR for HAV in water samples ranged between 0.2 (positive control) and $20 \mathrm{FFU} /$ $\mathrm{mL}$. Applying the nested PCR method, the detection limit of HAdV was 25 (positive control) and $250 \mathrm{TCID}_{50} / \mathrm{mL}$.

\section{DISCUSSION}

In Brazil, few studies have been developed in order to evaluate the presence of human enteric viruses in water samples using the adsorption-elution method with an
HA negatively charged membrane (Villar et al. 2006, De Paula et al. 2007, Guimarães et al. 2008, Miagostovich et al. 2008). A highly sensitive technique with high recuperation efficiency for virus detection is needed in order to ascertain the presence of these viruses in environmental samples. The recovery efficiency of the virus concentration method based on the use of an electronegative filter was previously evaluated for poliovirus (Katayama et al. 2002), noroviruses and sapoviruses from a sewage treatment plant (Haramoto et al. 2006, 2008), HAV (Villar et al. 2006) and astrovirus and norovirus (Victoria et al. 2009) from mineral water, tap water, river water and seawater. In this study, HAdV and HAV were used as a model for enteric viruses in order to assess the recovery efficiency of an adsorption-elution procedure from distilled water, seawater, lagoon water and treated wastewater effluent, using a combination of qualitative molecular methods (nested RT-PCR and nested PCR).

It should be noted that the recovery efficiencies estimated are purely for the purpose of orientation. The efficiency of a concentration method depends on many variables, such as the quantity of virus present in the sample, the nature and volume of the sample etc. (Albinana-Gimenez et al. 2009a). The recovery efficiency calculated from the method employed in this study is based on the viral detection limit of the positive control, which consisted of water samples seeded after the filtration step (100\%) and water samples seeded before the filtration step. Nested PCR and nested RT-PCR results in this study showed clear differences between environmental samples for HAdV and HAV. The lowest recov-

TABLE I

Efficiency of adenovirus recovery and viral detection limit by nested PCR in water samples

\begin{tabular}{lccc}
\hline Water sample & $\begin{array}{c}\text { Viruses inoculation before } \\
\text { the concentration method }\end{array}$ & $\begin{array}{c}\text { Viruses inoculation after } \\
\text { the concentration method }\end{array}$ & $\begin{array}{c}\text { Virus recovery } \\
(\%)\end{array}$ \\
\hline Distilled water & 25 & 25 & 100 \\
Lagoon water & 250 & 25 & 10 \\
Seawater & 250 & 250 & 10 \\
Treated wastewater effluent & 25 & 25 & 100 \\
\hline
\end{tabular}

values in $\mathrm{TCID}_{50} / \mathrm{mL}$.

\section{TABLE II}

Efficiency of hepatitis A viruses recovery and viral detection limit by nested RT-PCR in water samples

\begin{tabular}{lccc}
\hline Water sample & $\begin{array}{c}\text { Viruses inoculation before } \\
\text { the concentration method }\end{array}$ & $\begin{array}{c}\text { Viruses inoculation after } \\
\text { the concentration method }\end{array}$ & $\begin{array}{c}\text { Vírus recovery } \\
(\%)\end{array}$ \\
\hline Distilled water & 0.2 & 0.2 & 100 \\
Lagoon water & 2 & 2 & 100 \\
Seawater & 20 & 2 & 10 \\
Treated wastewater effluent & 2 & 2 & 100 \\
\hline
\end{tabular}

values in $\mathrm{FFU} / \mathrm{mL}$. 
ery efficiency $(10 \%)$ was found in seawater (Tables I, II) for HAdV and HAV. These results are in agreement with findings of previous studies that have demonstrated a low recovery yield from seawater (Villar et al. 2006, Victoria et al. 2009). Researchers studying viral detection in seawater in previous studies did not add salts to the sample, assuming that natural salts within the sample were sufficient to adsorb viruses onto the membrane (Pallin et al. 1997, Katayama et al. 2002). Victoria et al. (2009) demonstrated a low efficiency recovery of human astrovirus and norovirus from seawater when the samples were not treated with $\mathrm{MgCl}_{2}$, achieving the highest recovery treating the samples with $25 \mathrm{mM}$ or $50 \mathrm{mM}$ of $\mathrm{MgCl}_{2}$. Despite the low recovery yield for seawater in this study, we were able to obtain a detection limit by nested PCR of $250 \mathrm{TCID}_{50} / \mathrm{mL}$ and $20 \mathrm{FFU} / \mathrm{mL}$ for HAdV and HAV respectively, which is in accordance with previous studies (Katayama et al. 2002, Villar et al. 2006). We were able to achieve the same detection limit and $100 \%$ recovery efficiency for the distilled water and the treated wastewater effluent by comparing test samples with the positives controls of each sample for both viruses $\left(25 \mathrm{TCID}_{50} / \mathrm{mL}\right.$ for HAdV from distilled water and wastewater and 0.2 and $2 \mathrm{FFU} / \mathrm{mL}$ for $\mathrm{HAV}$ from distilled water and wastewater, respectively).

Molecular detection by qualitative PCR of adenoviruses, HAV and enteric viruses, when correctly applied, provides reliable data about the presence of these viruses in the environment. However, inhibition of amplification reactions by substances present in the samples, such as humic acids and metals, has been observed frequently in water samples (Albinana-Gimenez et al. 2009a). In addition, PCR is often unable to discriminate between infectious and inactivated virus (Reynolds et al. 1996, Ko et al. 2003). To improve the sensitivity of the detection methods, other molecular based protocols, such as real-time-PCR associated with virus viability, can also be used (Albinana-Gimenez et al. 2009b). Sensitive and practical methods for detecting enteric viruses in environmental waters are needed to determine the public health significance of these pathogens in the event of waterborne outbreaks of acute gastroenteritis. In this study, qualitative nested PCR and nested RT-PCR methods were capable of detecting HAdV DNA and HAV RNA in the water samples tested. In fact, improvements in the virus recovery method, such as treating seawater samples with $\mathrm{MgCl}_{2}$, must be made in order to obtain better recovery in this particular water sample. Nevertheless, the method was more efficient for the other kinds of water tested in this study. These results demonstrate the impact of the concentration method for the detection of HAV and HAdV by qualitative PCR; as a result, this method can be applied to monitor the presence of virus and the quality of environmental waters.

\section{ACKNOWLEDGMENTS}

To Ms. Doris Sobral Marques Souza, for the technical support in the PCR assays.

\section{REFERENCES}

Albinana-Gimenez N, Clemente-Casares P, Calgua B, Huguet JM, Courtois S, Girones R 2009a. Comparation of methods for con- centrating human adenovirus, polyomavirus JC and norovirus in source waters and drinking water using quantitative PCR. J Virol Methods 158: 104-109.

Albinana-Gimenez N, Miagostovich MP, Calgua B, Huguet JM, Matia L, Girones R 2009b. Analysis of adenovirus and polyomaviruses quantified by a PCR as indicators of water quality in source and drinking-water treatment plants. Water Res 43: 2011-2019.

Allard A, Albinsson B, Wadell G 1992. Detection of adenoviruses in stools from healthy persons and patients with diarrhea by twostep polymerase chain reaction. J Med Virol 37: 149-157.

Barardi CRM, Yip H, Emslie KR, Vesey G, Shanjer RS, Williams KL 1999. Flow cytometry and RT-PCR for rotavirus detection in artificially seeded oyster meat. Int J Food Microbiol 49: 9-18.

Bardell D 1983. In vitro exposure of adenovirus types 5 and 7 in oropharyngeal secretions to cigarette smoke. Appl Environ Microbiol 45: 770-773.

Boom R, Sol CJA, Salimans MMM, Jansen CL, Werthein-Van Dillen PME, Noordaa J 1990. Rapid simple method for purification of nucleic acids. J Clin Microbiol 28: 495-503.

Borchardt MA, Haas NL, Hunt RJ 2004. Vulnerability of drinkingwater wells in La Crosse, Wisconsin, to enteric-virus contamination from surface water contributions. Appl Environ Microbiol 70: 5937-5946.

Bosch A, Guix S, Sano D, Pinto RM 2008. New tools for the study and direct surveillance of viral pathogens in water. Curr Opin Biotechnol 19: 1-7.

Cromeans T, Sobsey MD, Fields HAJ 1987. Development of a plaque assay for a cytopathic, rapidly replicating isolate of hepatitis A virus. J Med Virol 22: 55-56.

de Paula VS, Lu L, Niel C, Gaspar AM, Robertson BH 2004. Genetic analysis of hepatitis A virus isolates from Brazil. J Med Virol 73: 378-383.

de Paula VS, Diniz-Mendes L, Villar LM, Luz SL, Silva LA, Jesus MS, Silva NM, Gaspar AM 2007. Hepatitis A virus in environmental water samples from the Amazon Basil. Water Res 41: 1169-1176.

Fong TT, Lipp EK 2005. Enteric viruses of human and animals in aquatic environments: heath risks, detection and potential water quality assessment tools. Microbiol Mol Biol Rev 69: 357-371.

Formiga-Cruz M, Hundesa A, Clemente-Casares P, Albiñana-Gimenez N, Allard A, Girones R 2005. Nested multiplex PCR assay for detection of human enteric viruses in shellfish and sewage. J Virol Methods 125: 111-118.

Formiga-Cruz M, Tofiño-Quesada G, Bofill-Mas S, Lees DN, Henshilwood K, Allard AK, Conden-Hansson AC, Hernroth BE, Vantarakis A, Tsibouxi A, Papapetropoulou M, Furones MD, Girones R 2002. Distribution of human virus contamination in shellfish from different growing areas in Greece, Spain, Sweden and the United Kingdom. App Environ Microbiol 68: 5990-5998.

Guimarães FR, Ferreira FF, Vieira CB, Fumian TM, Shubo T, Leite JP, Miagostovich MP 2008. Molecular detection of human astrovirus in an urban sewage treatment plant in Rio de Janeiro, Brazil. Mem Inst Oswaldo Cruz 103: 819-823.

Haramoto E, Katayama H, Oguma K, Ohgaki S 2005. Application of cationcoated filter method to detection of noroviruses, enteroviruses, adenoviruses and torque teno viruses in the Tamagawa River in Japan. Appl Environ Microbiol 71: 2403-2411.

Haramoto E, Katayama H, Oguma K, Ohgaki S 2007. Recovery of naked viral genomes in water by virus concentration methods. J Virol Methods 142: 169-173. 
Haramoto E, Katayama H, Oguma K, Yamashita H, Tajima A, Nakajima H, Ohgaki S 2006. Seasonal profiles of human noroviruses and indicator bacteria in a wastewater treatment plant in Tokyo, Japan. Water Sci Technol 54: 301-308.

Haramoto E, Katayama H, Phanuwan C, Ohgaki S 2008. Quantitative detection of sapoviruses in wastewater and river water in Japan. Lett Appl Microbiol 46: 408-413.

Harwood VJ, Levine AD, Scott TM, Chivukula V, Lukasik J, Farrah SR, Rose JB 2005. Validity of the indicator organism paradigm for pathogen reduction in reclaimed water and public health protection. Appl Environ Microbiol 71: 3163-3170.

Hsu B, Chen C, Kung C, Wan M, Shen S 2007. Evaluation of enterovirus recovery in surface water by different adsorption and elution procedures. Chemosphere 66: 964-969.

Katayama H, Shimasaki A, Ohgaki S 2002. Development of a virus concentration method and its application to detection of enterovirus and norwalk virus from coastal seawater. Appl Environ Microbiol 68: 1033-1039.

Kinsgley DH, Richards GP 2001. Rapid and efficient extraction method for reverse transcription-PCR detection of hepatitis A and Norwalk-like viruses in shellfish. Appl Environ Microbiol 67: 4152-4157.

Ko G, Cromeans TL, Sobsey MD 2003. Detection of infectious adenovirus in cell culture by mRNA reverse transcription-PCR. Appl Environ Microbiol 69: 7377-7384.

Lee SH, Lee C, Lee KW, Cho HB, Kim SJ 2005. The simultaneous detection of both enteroviruses and adenoviruses in envi- ronmental water samples including tap water with an integrated cell culture-multiplex-nested PCR procedure. J Appl Microbiol 98: 1020-1029.

Miagostovich MP, Ferreira FF, Guimarães FR, Fumian TM, DinizMendes L, Luz SL, Silva LA, Leite JP 2008. Molecular detection and characterization of gastroenteritis viruses occurring naturally in the stream waters of Manaus, central Amazônia, Brazil. Appl Environ Microbiol 74: 375-382.

Pallin R, Wyn-Jones AP, Place BM, Lightfoot NF 1997. The detection of enteroviruses in large volume concentrates of recreational waters by the polymerase chain reaction. J Virol Methods 67: 57-67.

Pusch D, Ihle S, Lebuhn M, Graeber I, López-Pila JM 2005. Quantitative detection of enteroviruses in activated sludge by cell culture and real-time RT-PCR using paramagnetic capturing. $J$ Water Health 3: 313-324.

Reed LJ, Muench H 1938. A simple method of estimating fifty percent endpoints. Am J Trop Med Hyg 27: 483-497.

Reynolds KA, Gerba CP, Pepper IL 1996. Detection of infectious enteroviruses by an integrated cell culture-PCR procedure. Appl Environ Microbiol 62: 1424-1427.

Victoria M, Guimarães F, Fumian T, Ferreira F, Vieira C, Leite JP, Miagostovich M 2009. Evaluation of an adsorption-elution method for detection of astrovirus and norovirus in environmental waters. J Virol Methods 156: 73-76.

Villar LM, De Paula VS, Diniz-Mendes L, Lampe E, Gaspar AM 2006. Evaluation of methods used to concentrate and detect hepatitis A virus in water samples. J Virol Methods 137: 169-176. 